\title{
CORONA-TEST OF THE REAL ECONOMY AND FINANCIAL AND ECONOMIC IMPERATIVES TO OVERCOME THE EFFECTS OF THE COVID-19 PANDEMIC
}

\author{
๑2020 PRIANYSHNYKOVA M. V., HUDENKO O. D.
}

UDC 336.773/57

JEL Classification: E59; F45

\author{
Prianyshnykova M. V., Hudenko O. D. \\ Corona-test of the Real Economy and Financial and Economic Imperatives to Overcome \\ the Effects of the COVID-19 Pandemic
}

\begin{abstract}
The article aims at highlighting the financial and economic imperatives and semantics of the practical ways for overcoming the negative effects of the COVID-19 pandemic by country, and finding capabilities for their implementation in Ukraine, taking into account the corona test results of the real economy expressed in the national measures of sustainable and comprehensive development, traditionally taken as a whole. The state of institutional and sectoral units of the real sector of economy during the COVID-19 global pandemic has been analyzed. The key factors of the negative impact on economic sustainability have been systematized based on the criterial invariance of the quantitative and qualitative indices of the production, logistics, labor availability (saving) and bankruptcy parameters. The research results in suggesting two types of measures to overcome the pandemic effects: the first one is at the enterprise level, and the second one is at the state level. The first group should include the companies' strategy decomposition, e.g. reducing costs, restructuring activities, diversifying production to meet the domestic market needs, supporting employees' mobility and engagement in remote work (online operation). The second group should include deferring tax payments, providing assistance (support) to enterprises and employees, state guarantees on loans, interest-free loans, one-time financial help, one-time grants for certain sectors, which are among the most sensitive ones to the COVID-19 pandemic effects. A critical analysis of the best practices in overcoming the pandemic effects in such countries as France, the USA, Germany, Great Britain, Italy, Turkey, Japan, China, South Korea and others has been carried out. Possible ways of their application in Ukraine have been offered.
\end{abstract}

Keywords: repayment holiday, interest-free loan, cash aid, tax breaks, losses, coronavirus, pandemic.

DOI: https://doi.org/10.32983/2222-0712-2020-3-18-24

Fig.: 1. Tabl.: 2. Bibl.: 19.

Prianyshnykova Marharyta V. - Postgraduate Student, Academy of Financial Management (38 Druzhby Narodiv Blvd., Kyiv, 01014, Ukraine)

E-mail: margarita.pryan@gmail.com

Hudenko Oleksandr D. - Postgraduate Student, Academy of Financial Management (38 Druzhby Narodiv Blvd., Kyiv, 01014, Ukraine)

E-mail: gud1970@gmail.com

УДК $336.773 / 57$

JEL Classification: E59; F45

Прянишникова М. В., Гуденко О. Д. Корона-тест реальної економіки та фінансово-економічні імперативи подолання наслідків пандемії COVID-19

Метою статті є висвітлення фінансово-економічних імператив і семантики практичних заходів щодо подолання негативних наслідків пандеміі COVID-19 в розрізі країн і потениійних можливостей їх імплементаиії в Україні з урахуванням результатів корона-тесту реальної економіки, вираженої в традиційній комбінації макроекономічних вимірників сталого й всеохоплюючого розвитку. У статті проаналізовано стан інституційносекторальних ланок реального сектора економіки в період світової пандемії COVID-19, систематизовано ключові фактори негативного впливу на сталість економічного зростання на базі критеріальної інваріантності вимірників кількісно-якісних параметрів виробництва, логістики, наявності (вивільнення) робочої сили та банкрутства. В результаті дослідження запропоновано виокремлення двох видів заходів щодо подолання наслідків пандемії: на рівні підприємств і держави. До першої групи запропоновано віднести декомпозицію стратегії компаній щодо скорочення витрат, перепрофілювання їх діяльності, продуктову диверсифікацію з урахуванням потреб внутрішнього ринку, забезпечення мобільності співробітників, їх залучення в інтерактивно-дистанційному режимі (онлайн-обслуговування). Друга виражена у допомозі (підтримці) підприємствам і найманим працівникам, відстрочиі податкових платежів, державних гарантіях по кредитах, надання безвідсоткових позик, одноразової фінансової допомоги, разових грантів для визначених секторів, які відносяться до найбільш чутливих у подоланні наслідків пандемії CoVID-19. Проведений критичний аналіз кращих практик подолання наслідків пандемії у таких країнах, як: Франція, США, Німеччина, Велика Британія, Італія, Туреччина, Японія, Китай, Південна Корея та ін. Запропоновано практичні кроки щодо можливості їх застосування в Україні.

Ключові слова: кредитні канікули, безвідсотковий кредит, грошова допомога, податкові послаблення, збитки, коронавірус, пандемія.

Рис.: 1. Табл.: 2. Бібл.: 19.

Прянишникова Маргарита Валентинівна - аспірант, Академія фінансового управління (бульв. Дружби Народів, 38, Київ, 01014, Україна)

E-mail: margarita.pryan@gmail.com

Гуденко Олександр Дмитрович - аспірант, Академія фінансового управління (бульв. Дружби Народів, 38, Київ, 01014, Україна)

E-mail: gud1970@gmail.com 
Introduction. Ukraine and the world have faced the COVID-19 pandemic, which is still gaining momentum and is bringing economic recession. According to IMF experts, the effects of the current crisis will overshadow the Great Recession of 2008 and will be the most difficult economic test for the world (the world economy is expected to fall by $3 \%$, which means that the world will produce about $\$ 2.7$ trillion less goods and services than it did in 2019 [1]). Despite the efforts of scientists around the world, it is still unknown when it will end and what consequences it will entail, economic above all. Needless to say, that COVID-19 has changed the world, from geopolitical aspects to the organization of life and leisure [2]. Worldwide, 819,609 people have been affected by COVID-19 ([3], as of August 26, 2020), which is approximately $0.01 \%$ of the world population, but the economic losses will be much greater. Sick people are detected by body temperature; if it is elevated, it means that the body is fighting the infection. For the economy, there is a similar «body indicator» as the change in gross domestic product (hereinafter, GDP). Like temperature, GDP does not show what the disease is, but only signals its presence. The GDP growth is a natural state of economy, because GDP is the total value of everything produced in a state for a year [1]. The world population is constantly growing, and people's needs and production volumes are growing, too. In some countries, living standards are improving: people are getting richer and consuming more goods (which also leads to the GDP growth). A fall in GDP indicates that something went wrong, and the «body» is experiencing some problems. Continuing this analogy, we can say that the world economy was gripped by fever.

Reduced sales and production, delayed deliveries, job cuts, forced vacations, bankruptcy, these are all things that modern business is facing. People may not only be suffering from the pandemic, but also losing the ability to pay their bills and survive. Businesses are already experiencing difficulties as supplies disappear, leaving them without products or raw materials. In regard of this is, the actual problem now is to find measures at the enterprise and state level, which could reduce and overcome the effects of the pandemic.

A lot of research works analyze measures to overcome the consequences of the COVID-19 pandemic, in particular: S.S. Gasanova suggests providing additional budget expenditures [12], T. I. Yefimenko proposes to introduce a system of tax benefits [13], O. M. Ivanytska considers these measures in the context of fiscal risks [14], M. V. Krippi, being the head of the «Try N» company, comes to the task at hand from a practical point of view and suggests a clear action plan to save businesses during the pandemic [10]. I. O. Liutyi considers the issue of attracting new direct investment from international companies [15], V. O. Makarov, an analyst at the «Evoplay» company, believes that the crisis is an occasion to review one's business, to reconsider the approach to business organization, and thinks that following trends should be the main measure taken [10].

The purpose of the article is to highlight practical measures to overcome the negative effects of the pandemic, to compare the situation by country and provide conclusions on the possibility to implement international experience in Ukraine. This purpose predetermines the solution of the following tasks: to analyze the current state of pandemic coverage; to study the negative factors that affect the activities of enterprises, em- ployees and the state as a whole; to classify types of measures to contain and overcome the pandemic effects; to analyze the other countries' experience during the pandemic; to assess the domestic measures to save the economy; to find out, whether there are areas that have managed to benefit from the pandemic through adapting to the new market conditions; having regard to the measures taken by other countries, to provide conclusions on the possibility of applying international experience in Ukraine.

Businesses around the world are forced to adapt faster than any other area, because it is impossible to overcome the pandemic, if the economy does not function. There are two types of measures to overcome the pandemic: at the enterprise level and at the state level.

Measures to overcome the pandemic at the enterprise level are that companies, for their part, try to quickly reduce costs, restructure their strategies, move to domestic markets, transfer employees to remote work, move to online services. One of the main changes caused by the pandemic is the growing recognition and usage of digital technologies at work and in everyday life [9, p. 4]. The majority on enterprises all oaver the world not only continue working under ambiguity, but also help the society and the state cope with new unexpected challenges.

For example, Jack Ma, the founder of Alibaba, using his charity fund, has donated 1.1 million test kits to detect coronavirus, 6 million masks, and 60,000 protective suits for African countries. Similar aid packages are being sent to the United States, Latin America and Asian countries. Other giant companies have also donated millions of dollars to fight COVID-19.

Industrial enterprises around the world are also reorienting their production accordingly to the new needs. For example, the Rolls-Royce is producing critically short devices for mechanical ventilators. Similar measures have been taken in the United States, where Ford, General Motors and Tesla are planning to produce ventilators and other necessary medical equipment.

Production lines of elite perfumes began to produce antiseptics. In pandemic countries, hotel chains have begun to repurpose their rooms to hospitals, providing them free of charge to doctors and technicians who are fighting the spread of the infection [10].

Let us highlight the main measures at the state level, which are aimed at overcoming the effects of the pandemic:

- economic assistance to enterprises and employees;

- deferral of tax payments;

- state guarantees on loans;

- interest-free loans, provided that all jobs are preserved;

- loan deferral;

- one-time financial assistance;

- one-time grants for areas most affected by the pandemic (airlines, airports, pubs, clubs, theaters and others);

- vouchers to working parents to compensate for babysitting services, etc.

The governments of all the countries are taking measures to mitigate the impact on the national and world economy. Let us consider in detail the measures and financial injections of states to overcome the effects of the pandemic and support the economy (fig. 1). 
Authorities in France have allocated \$ 545 billion to combat the effects of the coronavirus [11]. In addition, the government is providing economic assistance to businesses and employees in the amount of 45 billion euros. Starting with march, the French government is granting a reprieve for all taxes and social payments. Besides, they are considering a possibility ti cancel these payments for those who are threatened with bankruptcy. In addition, the government is providing state guarantees for loans in the amount of 300 billion euros to small and medium enterprises.

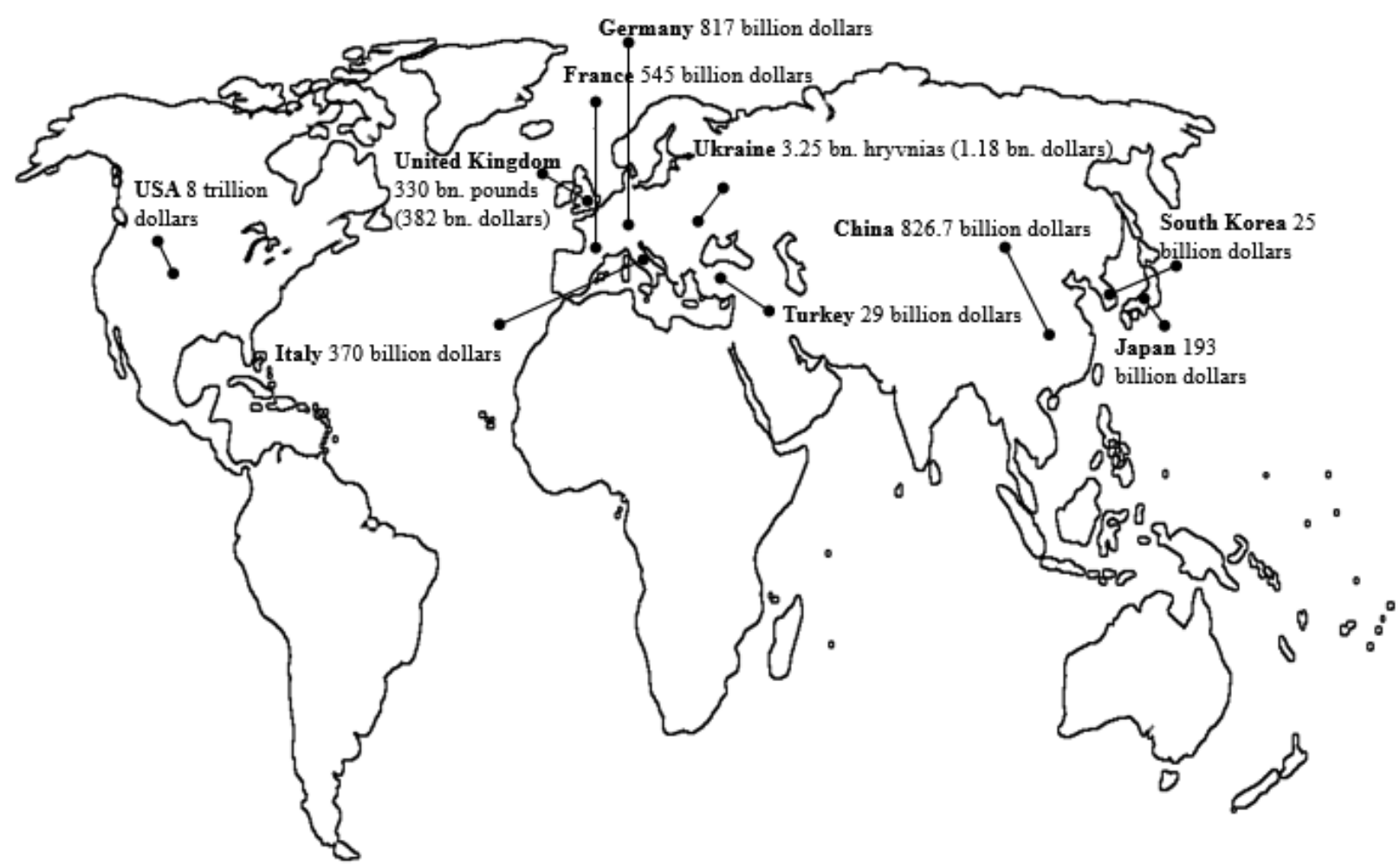

Fig. 1. Financial injections in the countries for the last six months to eliminate the effects of coronavirus and support the economy, in USD

Source: $[4 ; 5]$

To combat the effects of coronavirus, the United States have allocated $\$ 8$ trillion (the government has allocated $\$ 2$ trillion, the Federal Reserve has allocated $\$ 6$ trillion) [11]. Under the Paycheck Protection Program the government gives businesses a zero-interest loan of $\$ 1.8$ billion If all the jobs are preserved, the borrowed funds may not be returned. In addition, no interest will be charged on higher education loans during the pandemic. And each family will receive a one-time financial assistance of $\$ 3,000$ [12].

$\$ 817$ billion has been allocated in Germany to combat the effects of the coronavirus [11]. Germany, like the USA, has emergency financial assistance programs for businesses that have suffered losses because of the pandemic (the decision on giving financial support is taken 1 to 3 days from the date of request. If a business executive has to close down, but keeps the jobs, he/she can receive up to three tranches in the amount of 3 to 5 thousand euros (i.e., in total, from 9 to 15 thousand euros). The Investment Bank of Berlin has already provided more than 140,000 of such tranches from the budget, spending a total of one and a half billion euros [13].

In the UK, the government has decided to allocate $£ 330$ billion to support businesses affected by the coronavirus outbreak [11]. This amount is called unprecedented: it is about $15 \%$ of the British GDP and more than a third of the UK budget (however, the number of infected is also critical, 326,614 people as of 26.08.2020 [3]).

The government is preparing, in particular, to support the aviation sphere that has suffered most from the quarantine and the closure of borders and suggest one-time grants of up to $£ 25,000$ each for enterprises from other spheres that have suffered greatly, e.g. pubs, clubs, theatres, so that they could survive this difficult time.

The government has announced that during the next fiscal year, any business in the retail, leisure or hotel business valued at less than $£ 51,000(\$ 65,670)$ will not pay taxes on commercial real estate in the UK.

In Italy, which suffered most from the coronavirus, the government adopted a decree allocating $€ 25$ billion to cover losses from coronavirus, and introduced special measures to save the economy, but in six months this amount reached \$ 370 billion [11]. At least 3.5 billion euros will be allocated to finance the health care system. Payments on loans and mortgages to businesses and individuals will be suspended, they will be covered by state guarantees for banks.

The Italian government is providing special payments for individuals, namely: 600 euros vouchers to compensate for babysitting services, for the working parents with children under 12. Parents working in the private sector can go on a paid 
leave and receive up to $50 \%$ of the allowance, if they have a child under the age of 12 .

All employees with a total income of no more than 40,000 euros per year, who continue to work in quarantine and emergency conditions, will be able to receive a small bonus, up to 100 euros. A total of $€ 10$ billion is provided to support families and businesses [12].

Turkey has allocated 200 billion lire, equivalent to \$29 billion, to support its economy in the pandemic. In Turkey, a boosting package of $\$ 15.5$ billion is provided for businesses affected by the coronavirus. The Turkish Shield of Economic Stability Program aims to protect small businesses, exporters, employees and retirees The Turkish government is to increase the minimum pension to $\$ 231$ (1,500 Turkish lira) and redirect an additional $\$ 308$ million (2 billion Turkish lira) to needy households. $[11 ; 12]$ A home health care program is being introduced for retirees. The plan to support Turkish business also includes a three-month deferral of payments on business loans and additional financial support, and an individual standard for the tourism sector. VAT for domestic air transportation has been reduced from $18 \%$ to $1 \%$ for three months, and the residence tax has been abolished till November.

Social contributions have been deferred for six months for retail trade, metallurgical industry, shopping centers, automobile industry, entertainment and hotel business, food and beverage production, textiles, as well as for events [12].

In Japan, about $\$ 4$ billion has been allocated to support small and medium-sized businesses. An additional \$ 193 billion was allocated to stimulate the economy $[11 ; 12]$. The rest of the budget will go to compensate parents who were forced to take leave or discharge due to the quarantine of educational institutions.

China began to support its economy in February. At that time, the Chinese government allocated more than $\$ 10$ billion. Chinese companies were offered tax breaks, soft loans, and delivery services were exempt from VAT. The People's Bank of China spent a total of about 5.9 trillion yuan ( $\$ 826.7$ billion) on economic support measures through injections into the financial system, by stimulating banks to grant cheap loans, and reducing the reserve ratio for banks [5].

South Korea has allocated about \$ 25 billion to stimulate the economy. The government has also adopted a package of tax measures to support the economy in connection with the spread of COVID-19 totaling 7 trillion won (\$ 5.9 billion). For example, landlords will be granted a $50 \%$ tax credit, if they agree to reduce the rent for affected businesses.

Consumption taxes when buying cars are reduced by $70 \%$ to support the market. In addition, enterprises with an annual turnover of less than 60 million won (about $\$ 45$ thousand) receive VAT benefits without disclosing additional information [12].

The two giants of the world economy, the United States and China, are among the most affected by the pandemic, thus affecting the others. Countries are trying to mitigate the effects of the pandemic through anti-crisis measures, but unlike countries like Germany and the UK, where funding is estimated at hundreds of billions of euros, Ukraine does not have such reserves, so domestic companies can not count on multibillion support packages from the government, or compensate salaries and wages to their employees.
As of June, Ukraine allocated more than UAH 3.2 billion was from the state budget and local budgets. to counter the pandemic.

The Government of Ukraine has approved a program titled «Economic Recovery» to stimulate the economy and overcome the effects of COVID-19.. Life with the pandemic will last more than a year, and there only are three possible options in this situation: the creation of group immunity through the complete abolition of the quarantine; quarantine until the treatment or vaccination against COVID-19 are provided; adaptive quarantine, strict control over COVID-19 and economic recovery $[14$, p. 6$]$.

Having analyzed the risks of alternative scenarios, the Cabinet of Ministers of Ukraine decided to announce the transition to an adaptive quarantine model. The governmental economic stimulus program to overcome the effects of the COVID-19 pandemic is designed for 2020-2022. To support the economy, the program provides measures to stimulate the economy in the following sectors [14, p. 41]: industry, agriculture, energy, transport and infrastructure, information and communication technologies, services. The economy should also be supported by functional areas [14, p. 19]: small and medium business; international trade, investment and innovation; job creation and labor market development; reasonable regulation of economic activity.

In order to support business executives, the self-employed and ordinary employees during the coronavirus period, Ukraine is introducing repayment holidays. The main condition for obtaining an interest-free loan is that the borrower retains at least $60 \%$ of the payroll and $80 \%$ of jobs compared to March 1,2020 , which will restrain job cuts; the amount of annual income from economic activity should not exceed 10 million euros; absence of non-performing loans as of March 1, 2020.

The Ministry of Economic Development, Trade and Agriculture of Ukraine and the Ministry of Finance of Ukraine have proposed loan support programs. Let us consider the terms of the new state program, «Affordable loans 5-7-9 \%», and its main parameters.

The first parameter is interest compensation. For clients with revenue from UAH 25 to 50 million. additional interest rate compensation is offered, being 0.5 percentage points for each client. The participant's own contribution should be up from $20 \%$ of the project amount for an operating business, and up from $30 \%$ of the project amount for a newly created business [7].

Purpose of the loan:

- Acquisition of new and used fixed assets, their modernization;

- Acquisition of non-residential real estate without the right to lease;

- Construction and reconstruction of premises (except offices);

- Acquisition of intellectual property rights (franchising);

- Replenishment of working capital up to $25 \%$ of the investment project cost.

The second parameter is credit guarantees. Credit guarantees are provided on loans to micro and small enterprises that do not have sufficient assets to transfer them as collateral for the loan or are characterized by increased credit risks, such as start- 
Characteristics of the main conditions of the state program «Affordable loans 5-7-9\%»

\begin{tabular}{|c|c|c|c|}
\hline Lending program & $5 \%$ per annum & $7 \%$ per annum & $9 \%$ per annum \\
\hline Loan currency & UAH & UAH & UAH \\
\hline Income level & annual income up to UAH 50 million & $\begin{array}{l}\text { annual income up to UAH } 50 \\
\text { million }\end{array}$ & $\begin{array}{l}\text { annual income from UAH } 50 \\
\text { million up to UAH } 100 \text { million }\end{array}$ \\
\hline Jobs creation & $\begin{array}{l}\text { subject to hiring at least } 2 \text { new } \\
\text { employees throughout one quarter }\end{array}$ & not a prerequisite & $\begin{array}{l}\text { for each new job, the interest rate } \\
\text { is reduced by } 0.5 \% \text { per annum, } \\
\text { but is not less than } 5 \% \text { per } \\
\text { annum }\end{array}$ \\
\hline \multirow[b]{2}{*}{ Loan purpose } & $\begin{array}{l}\text { loan on financing an investment } \\
\text { project for micro and small business } \\
\text { owners }\end{array}$ & $\begin{array}{l}\text { loan on financing an investment } \\
\text { project for micro and small } \\
\text { business owners }\end{array}$ & $\begin{array}{l}\text { loan on financing an investment } \\
\text { project for micro and small } \\
\text { business owners }\end{array}$ \\
\hline & $\begin{array}{l}\text { loan to replenish working capital } \\
\text { required for the implementation } \\
\text { of the investment project in the } \\
\text { amount of up to } 25 \% \text { of the cost } \\
\text { (granted only together with an } \\
\text { investment loan) }\end{array}$ & $\begin{array}{l}\text { loan to replenish working capital } \\
\text { required for the implementation } \\
\text { of the investment project in the } \\
\text { amount of up to } 25 \% \text { of the cost } \\
\text { (granted only together with an } \\
\text { investment loan) }\end{array}$ & $\begin{array}{l}\text { loan to replenish working capital } \\
\text { required for the implementation } \\
\text { of the investment project in the } \\
\text { amount of up to } 25 \% \text { of the cost } \\
\text { (granted only together with an } \\
\text { investment loan) }\end{array}$ \\
\hline
\end{tabular}

Source: [7]

Maximum conditions of the state program «Available loans 5-7-9 \%»

\begin{tabular}{|l|l|}
\hline \multicolumn{1}{|c|}{ The maximum loan amount } & \multicolumn{1}{|c|}{ up to UAH 3 million } \\
\hline Maximum loan term & $\begin{array}{l}\text { - up to } 5 \text { years for investment projects; } \\
\text { - up to } 2 \text { years for loans on renewal working capital. }\end{array}$ \\
\hline The maximum amount of the bank's commission & \\
\hline
\end{tabular}

Source: [7]

ups. Due to these credit guarantees, the state, through the Entrepreneurship Development Fund, covers part of the credit risk of small and micro businesses (hereinafter referred to as SMB), creating conditions for receiving bank loans. Guarantee fee is $0.5 \%$ per annum of the amount owed on the SMB loan.

Level of guarantee coverage for an existing business is $50 \%$ of the amount owed on a SMB loan; for a newly established business it is $80 \%$ of the amount owed on a SMB loan. Government support in the form of credit guarantees is provided exclusively together with interest compensation on SMB loans that meet the requirements of the program. [15]

The third parameter is anti-crisis measures. In order to minimize the negative consequences for the development of small business due to the need to implement a quarantine regime, an additional component has been introduced within the program for financial support of SMBs. The anti-crisis SMB support package was introduced during the quarantine or restrictive measures and within 90 days from the date of their cancellation [15].

Let us highlight the main directions of anti-crisis measures:

- support for investment projects related to the production of medicines, medical devices, medical equipment, as well as refinancing of SMB loans for concrete goals;

- support of SMB liquidity on account of a working capital loan to cover fixed costs (to pay the salaries and wages, rent and utility bills, etc.) without reference to the costs of the investment project;

- refinancing the existing debt on SMB loans in banks by: granting a new loan, changing the terms of the current loan (providing it with state support in the form of interest compensation under the program) [15].

Currently, one can get a loan under the program «Affordable loans 5-7-9 \%» in four partner banks of the public sector, namely, «PrivatBank», «Oshchadbank», «Ukrgasbank», «UkrEximBank» and three commercial partner banks, namely, «Lviv», «Alliance Bank» and «PUMB» [16].

Thus, this program will help support the business, but there are some nuances, because sometimes the lending program is not approved, and the company is trapped, as it took a loan, began to pay interest, at first they were received compensations and then the funds ended, the program did not continue, and the company had to pay the loan service on its own.

Part of the funds allocated for the program was provided for starting a new business, but under the current conditions, according to experts [13], it would be more appropriate to allocate the funds to the existing businesses, which are currently suffering from the quarantine measures.

The Verkhovna Rada of Ukraine, in addition to credit vacations, promised to support Ukrainian business executives with tax breaks, a freeze on fines and penalties, and a moratorium on inspections. To control the national currency the Na- 
tional Bank of Ukraine is conducting interventions. The state has paid a one-time cash benefit in the amount of UAH 1,000 to pensioners (whose pension does not exceed UAH 5,000 as of April 1,2020), recipients of state social assistance to persons with disabilities from childhood and children with disabilities, recipients of state social assistance to persons not entitled to a pension, recipients of temporary state social assistance benefits to an unemployed person who has reached the general retirement age but has not acquired the right to a pension payment. The Government has allocated UAH 10.6 billion for this purpose [17].

The world is anxious, many countries are looking for ways to support their economies and businesses. However, some areas have not only been able to avoid losses, but also to earn billions by adapting to new market conditions. One of such companies is «Zoom», which helps a large number of people to communicate by video, so that in the situation of mass transition to remote work it is used by businesses, universities and educational institutions. For many people in isolation, such services have become an opportunity to earn at least some income, as Zoom has been actively used by microbusiness representatives and self-employed people, who conduct online courses, trainings, lectures, excursions, etc.

One more industry that has been boosted by the coronavirus has been the online entertainment industry. When the quarantine was introduced, people became more active in using services that allow you to watch movies and TV series, listen to music and play video games online (Netflix and YouTube).

During the forced quarantine, not only video services but also the computer game industry took off, and during the pandemic, computer games became not only a way of entertainment. Video games are effective in curbing the spread of the virus by forcing people to stay at home. Among the beneficiaries of the coronavirus crisis are pharmaceutical companies and online retailers (Amazon and others).

So, all business executives should take the pandemic as an opportunity for reassignment and reshaping of their business, using their knowledge and skills. They should try to learn the new demand of the society, and stimulate their business, accordingly [18, p. 1170].

However, during an economic crisis, people tend to cut buying any goods (including entertainment), but they will always buy food, so the agricultural sector is also less sensitive to the quarantine and it can grow significantly compared to the industrial sector.

Conclusion. Having analyzed the measures to overcome the pandemic both at the enterprise level and at the state level, we propose to implement the following steps of international experience in Ukraine, namely:

Measures at the state level:

- to grant enterprises that do not carry out their activities or cannot use the leased space to make a profit, relief from lease payments;

- to reduce the tax burden or defer the payment of taxes. For example, to defer the unified social tax, as due to the high labor costs, many companies operate in the shadow sector, because if they star working properly, they will go bankrupt. Reducing the tax burden will also contribute to the positive creditworthiness of borrowers (because it will reflect the real turnover) and will provide an opportunity to obtain a positive conclusion on the loan. Additionally, enterprises can be provided with the deferral of paying the income tax and the personal income tax.

Measures at the enterprises level:

- we recommend developing online activities, if the specifics of the enterprise allow it. As we can see from foreign experience, some areas have been able to earn billions by adapting to new market conditions;

- it is necessary to reduce costs. There are two types of costs: strategic and non-strategic costs [7]. The first group includes those costs that ensure the operation of the company to make a profit. The second one includes everything else (for example: renting an office, organizing teambuilding activities, buying lunches, coffee, etc.). It is important to focus on the second group, but it is necessary to remember about the employees, inform them about the temporary nature of such actions, and make informed decisions.

First of all, in times of crisis, it is important to be able to adapt, be flexible and ready for change. It is appropriate to mention a statement by Charles Darwin: «It is not the strongest or the smartest that survives, but the one who best adapts to changes» [19].

In addition to the above steps to support and save business, as well as to overcome the crisis, business leaders and the state must always be at the ready, monitor the market every day, monitor the others' trends and decisions and borrow the successful ones.

\section{LITERATURE}

1. Вінакуров Я. Нова Велика депресія: наслідки коронавируса для світової і української економіки // Громадское телевидение. URL: https://hromadske.ua/ru/posts/novaya-velikayadepressiya-posledstviya-koronavirusa-dlya-mirovoj-i-ukrainskojekonomiki

2. Горбулін В. П., Даник Ю. Г. Національна безпека України: фокус пріоритетів в умовах пандемії. Вісник Національної академії наук України. 2020. № 5. С. 3-18.

3. Коронавірус (COVID-19). Світова статистика // Google Новини, 2020. URL: https://news.google.com/covid19/ map?hl=uk\&mid $=/ \mathrm{m} / 02 \mathrm{j} 71 \& \mathrm{gl}=\mathrm{UA} \&$ ceid=UA:uk

4. Гасанов С.С., Кудряшов В.П., Балакін Р.Л.Наднаціональні фіскальні правила та координація бюджетної політики в Європейському Союзі. Фінанси України. 2019. № 3. С. 37-55.

5. Соколовська А. М., Єфименко Т. І., Луніна І. О. Система податкових пільг в Україні в контексті європейського досвіду. Київ : НДФІ, 2006. 320 с.

6. Іваницька О. М., Кощук Т. В. Методологічні засади ідентифікації фіскальних ризиків. Фінанси України. 2018. № 6. C. 45-57.

7. Корона-кризис: Максим Криппа и другие эксперты о том, как бизнесу спастись от вирусного вулкана // Мінфін. URL: https://minfin.com.ua/2020/07/02/48143078/

8. Лютий І. О., Боринець С. Я., Варналій 3. С. Фінанси : підручник. Київ : Ліра-К, 2017. 720 с.

9. Shaker A. Zahra International entrepreneurship in the post Covid world. Journal of World Business. 2020. URL: https:// reader.elsevier.com/reader/sd/pii/S1090951620300717?token=5D 
D745C9B847BA524227D98E5C4EABA58D73F925F950154E3E188 607895A4AE0EE72808497550F5DD737A17A7E56FA4F

10. Рука допомоги. Як світовий та український бізнес справляється з пандемією коронавірусу і допомагає іншим пережити кризу // РБК-Україна. URL: https://www.rbc.ua/static/ longread/helping_hand_ukr/index.html

11. Скільки коштів зарубіжні країни витратять на боротьбу з COVID-19? // Znak. URL: https://www.znak.com/2020-04-14/ skolko_sredstv_zarubezhnye_strany_potratyat_na_borbu_s_ covid_19

12. Бровінська М. На які заходи йдуть уряди, щоб врятувати економіки своїх країн. 16 прикладів // ЛігаБизнес. URL: https://ua-news.liga.net/economics/articles/na-yaki-zahodi-yduturyadi-schob-vryatuvati-ekonomiki-svoih-krain-22-prikladi

13. Обух В. Кредит під $0 \%$ під час карантину - це реальність. Як це працюватиме? // Ukrinform. URL: https://www. ukrinform.ua/amp/rubric-economy/3007502-kredit-pid-0-pid-caskarantinu-ce-realnist-ak-ce-pracuvatime.html

14. Програма стимулювання економіки для подолання наслідків COVID-19: «Економічне відновлення». URL: https://www.kmu.gov.ua/storage/app/sites/1/18\%20-\%20Depart ment/18 \%20- \%20PDF/07.2020/programa.pdf

15. Доступні кредити 5-7-9 \% // Державний Портал для підприємців. URL: https://5-7-9.gov.ua/

16. Уряд розширив можливості програми «Доступні кредити 5-7-9 \%» // Державні сайти України, Урядовий портал. URL: https://www.kmu.gov.ua/news/uryad-rozshiriv-mozhlivostiprogrami-dostupni-krediti-5-7-9

17. Мінсоцполітики: Розпочато виплати одноразової грошової допомоги у розмірі 1000 гривень // Урядовий портал. URL: https://www.kmu.gov.ua/news/minsocpolitiki-rozpochatoviplati-odnorazovoyi-groshovoyi-dopomogi-u-rozmiri-1000griven

18. Inshan Meahjohn, Prakash Persad. The Impact of COVID19 on Entrepreneurship Globally. The Asian Institute of Research. Journal of Economics and Business. 2020. Vol. 3. No. 3. P. 109-122.

19. Чарльз Дарвин // Socratify.net. URL: https://socratify. net/quotes/charlz-darvin/249044

\section{REFERENCES}

Brovinska, M."Na yaki zakhody idut uriady, shchob vriatuvaty ekonomiky svoikh krain. 16 prykladiv" [What Measures Do Governments Take to Save Their Economies? 16 Examples]. LihaByznes. https://ua-news.liga.net/economics/articles/na-yaki-zahodi-yduturyadi-schob-vryatuvati-ekonomiki-svoih-krain-22-prikladi

"Charlz Darvin" [Charles Darwin]. Socratify.net. https://socratify.net/quotes/charlz-darvin/249044

"Dostupni kredyty 5-7-9 \%" [Available Loans 5-7-9 \%]. Derzhavnyi Portal dlia pidpryiemtsiv. https://5-7-9.gov.ua/

Hasanov, S. S., Kudriashov, V. P., and Balakin, R. L. "Nadnatsionalni fiskalni pravyla ta koordynatsiia biudzhetnoi polityky $v$ Yevropeiskomu Soiuzi" [Supranational Fiscal Rules and Fiscal Policy Coordination in the European Union]. Finansy Ukrainy, no. 3 (2019): 37-55.

Horbulin, V. P., and Danyk, Yu. H. "Natsionalna bezpeka Ukrainy: fokus priorytetiv v umovakh pandemii" [National Security of Ukraine: Focus of Priorities in a Pandemic]. Visnyk Natsionalnoi akademii nauk Ukrainy, no. 5 (2020): 3-18.

Inshan, Meahjohn, and Prakash, Persad. "The Impact of COVID19 on Entrepreneurship Globally. The Asian Institute of Research". Journal of Economics and Business, vol. 3, no. 3 (2020): 109-122.
Ivanytska, O. M., and Koshchuk, T. V. "Metodolohichni zasady identyfikatsii fiskalnykh ryzykiv" [Methodological Bases of Identification of Fiscal Risks]. Finansy Ukrainy, no. 6 (2018): 45-57.

"Korona-krizis: Maksim Krippa i drugiye eksperty o tom, kak biznesu spastis ot virusnogo vulkana" [Coronacrisis: Maxim Krippa and Other Experts on How Businesses Can Escape a Viral Volcano]. Minfin. https://minfin.com.ua/2020/07/02/48143078/

"Koronavirus (COVID-19). Svitova statystyka" [Coronavirus (COVID-19). World Statistics]. Google Novyny, 2020. https://news.google.com/covid 19/map?hl=uk\&mid=/ $\mathrm{m} / 02 \mathrm{j} 71 \& \mathrm{gl}=$ UA\&ceid=UA:uk

Liutyi, I. O., Borynets, S. Ya., and Varnalii, Z. S. Finansy [Finances]. Kyiv: Lira-K, 2017.

"Minsotspolityky: Rozpochato vyplaty odnorazovoi hroshovoi dopomohy u rozmiri 1000 hryven" [Ministry of Social Policy: Payment of One-time Financial Assistance in the Amount of UAH 1,000 Has Started]. Uriadovyi portal. https://www.kmu.gov.ua/ news/minsocpolitiki-rozpochato-viplati-odnorazovoyi-groshovoyi-dopomogi-u-rozmiri-1000-griven

Obukh, V. "Kredyt pid $0 \%$ pid chas karantynu - tse realnist. Yak tse pratsiuvatyme?" [A Loan at $0 \%$ During Quarantine Is a Reality. How Will It Work?]. Ukrinform. https://www.ukrinform.ua/ amp/rubric-economy/3007502-kredit-pid-0-pid-cas-karantinu-cerealnist-ak-ce-pracuvatime.html

"Prohrama stymuliuvannia ekonomiky dlia podolannia naslidkiv COVID-19: «Ekonomichne vidnovlennia»" [Economic Stimulus Program to Overcome the Consequences of COVID-19: «Economic Recovery»]. https://www.kmu.gov.ua/storage/app/sites/1/18 \%20- \%20Department/18 \%20- \%20PDF/07.2020/programa.pdf

"Ruka dopomohy. Yak svitovyi ta ukrainskyi biznes spravliaietsia z pandemiieiu koronavirusu i dopomahaie inshym perezhyty kryzu" [Helping Hand. How Global and Ukrainian Business Is Coping with the Coronavirus Pandemic and Helping Others Survive the Crisis]. RBK-Ukraina. https://www.rbc.ua/static/longread/helping_hand_ukr/index.html

"Skilky koshtiv zarubizhni krainy vytratiat na borotbu z COVID-19?" [How Much Money Will Foreign Countries Spend on the Fight Against COVID-19?]. Znak. https://www.znak.com/2020-0414/skolko sredstv zarubezhnye strany_potratyat na_borbu_s covid_19

Shaker, A. "Zahra International entrepreneurship in the post Covid world". Journal of World Business. 2020. https://reader.elsevier.com/reader/sd/pii/S1090951620300717?token=5DD745C9B84 7BA524227D98E5C4EABA58D73F925F950154E3E188607895A4AE OEE72808497550F5DD737A17A7E56FA4F

Sokolovska, A. M., Yefymenko, T. I., and Lunina, I. O. Systema podatkovykh pilh $v$ Ukraini $v$ konteksti yevropeiskoho dosvidu [The System of Tax benefits in Ukraine in the Context of European Experience]. Kyiv: NDFI, 2006.

"Uriad rozshyryv mozhlyvosti prohramy «Dostupni kredyty 5-7-9 \%»" [The Government Has Expanded the Capabilities of the Program «Affordable Loans 5-7-9 \%»]. Derzhavni saity Ukrainy, Uriadovyi portal. https://www.kmu.gov.ua/news/uryad-rozshirivmozhlivosti-programi-dostupni-krediti-5-7-9

Vinakurov, Ya. "Nova Velyka depresiia: naslidky koronavyrusa dlia svitovoi i ukrainskoi ekonomiky" [The New Great Depression: Consequences of the Coronavirus for the World and Ukrainian Economies]. Gromadskoye televideniye. https://hromadske.ua/ ru/posts/novaya-velikaya-depressiya-posledstviya-koronavirusadlya-mirovoj-i-ukrainskoj-ekonomiki

Стаття надійшла до редакції 03.08.2020 p. 